\title{
The Genetics of Obsessive-Compulsive Disorder
}

\author{
Michael H. Bloch, M.D., M.S. "\# and Christopher Pittenger, M.D., Ph.D.\# \\ *Yale Child Study Center, Yale University School of Medicine, New Haven, Connecticut \\ \#Department of Psychiatry, Yale University School of Medicine, New Haven, Connecticut
}

\begin{abstract}
OCD is a psychiatric disorder with a lifetime prevalence of $1-3 \%$ and is a significant cause of disability worldwide. Family studies indicate that OCD has a significant hereditable component, with relatives of OCD cases being 4 times more likely to develop the disorder than the general population. Linkage studies in OCD have generally been underpowered and have failed to reach the statistical threshold for genome-wide significance, but they have nevertheless been useful for revealing potential regions of interest for future candidate gene studies. Candidate gene studies in OCD have thus far focused on genes involved in the serotonergic, dopaminergic, and glutamatergic pathways. These studies have been for the most part inconclusive, and failures to replicate have been the norm until very recently. The only genetic association replicated by multiple groups was with a glutamate transporter gene (SLC1A1). Genome-wide association studies in OCD are in progress, but final results have not yet been reported. As with the study of many other psychiatric disorders, an improved understanding of OCD will only be achieved (1) with larger collaborative efforts involving more probands, (2) the use of probands and controls drawn from epidemiologically-based populations rather than clinical samples, (3) developing a more precise phenotypic description of OCD and (4) measuring important environmental influences that affect OCD pathogenesis and severity.
\end{abstract}

\section{Keywords}

Obsessive-compulsive disorder; genetics

\section{Introduction}

Obsessive-compulsive disorder (OCD) is a psychiatric illness characterized by obsessions (bothersome, intrusive thoughts, images and impulses) and compulsions (stereotyped mental or physical rituals designed to relieve the anxiety associated with obsessions). OCD has a lifetime prevalence of 1-3\% and represents a substantial source of disability worldwide (1, 2). OCD symptom type and structure is remarkably similar across development and crossculturally (3). OCD has a bimodal distribution of onset and affects both children and adults $(4,5)$.

Effective pharmacological and behavioral treatments for OCD have been developed over the past three decades. First-line treatments for OCD, such as selective-serotonin reuptake inhibitors (SSRIs) and cognitive behavioral therapy significantly, benefit one-half to two-

Correspondence: Michael H. Bloch, MD, MS Child Study Center, Yale University School of Medicine, PO Box 2070900, New Haven, CT 06520 or Michael.bloch@yale.edu; Christopher Pittenger, MD, Ph.D., Department of Psychiatry, Yale University School of Medicine, 34 Park Street W315, New Haven, CT 06508 or Christopher.pittenger@yale.edu.

Disclosures: The authors have no conflicts of interest to disclose 
thirds of children and adults with OCD $(6,7)$. Although our current treatments for OCD substantially improve symptoms in a majority of cases, they cannot be considered adequate, for several reasons. Most individuals with OCD still experience substantial residual symptoms, even after successful initial treatment. A sizeable proportion of OCD patients, at least a quarter, do not improve with current treatments. Finally, currently available treatments for OCD take a long time to work (typically $2-3$ months in the case of SSRIs and CBT). Novel therapies, and the new insights into the pathophysiology of the disorder that will generate them, are urgently needed. Understanding the genetics of OCD will provide one important route towards this goal.

Here we review genetic studies conducted to date in obsessive-compulsive disorder (OCD). We will begin by discussing the heritability of OCD, by reviewing twin and family studies of OCD. Linkage studies have identified chromosomal regions of potential interest in OCD; we review these, and candidate gene association studies that have largely focused on genes in these identified regions. Until recently, positive associations with OCD risk have not been replicated and must be viewed as tentative. We conclude by discussing collaborative genome-wide association studies currently underway and addressing methods for improving the overall quality genetic studies in OCD.

\section{Heritability of OCD}

\section{Twin Studies}

Twin studies use the fact that monozygotic (MZ) twins are genetically identical, while dizygotic (DZ) twins share on average 50\% of their segregating genes (similar to any set of non-twin siblings). Since twins typically experience similar environments, any difference in concordance rates between MZ and DZ twins is indicative of genetic influence on a trait.

Three epidemiologic twin studies have been conducted in OCD (8). Carey and Gottesman recruited thirty consecutive twin pairs (15 MZ and $15 \mathrm{DZ}$ ) from the Maudsley Twin Register in which at least 1 member had obsessional symptoms according to DSM-III criteria (9). They reported an $87 \%$ concordance rate for MZ twins and a $47 \%$ concordance rate for DZ twins for "obsessional symptoms or features with or without treatment (9)." For "obsessional symptoms were required to be severe enough to warrant treatment," concordance rates were 33\% for MZ twins and 7\% for DZ twins (9). These concordance rates suggest a heritable component of OCD, but methodological limitations of this study such as lack of interviewer blinding to zygosity status of the pair introduces the potential of a detection bias. Smaller epidemiological twin studies designed to measure the heritability of anxiety disorders in general failed to uncover any concordant MZ or DZ twin pairs and thus were unable to measure the heritability for $\operatorname{OCD}(10,11)$. The low prevalence of OCD in epidemiologically-based samples limits the statistical power of this approach.

More recent epidemiologically-based twin studies have employed dimensional approaches to quantitatively assess the heritability of obsessive and compulsive symptoms in nonaffected twin pairs (8). One study used 20 items from the Padua Inventory to assess the heritability of 527 adult female twin pairs from the Virginia Twin Registry (12). This study used structural equation modeling to attribute $33 \%$ of obsessiveness and $26 \%$ of compulsiveness to heritability and the remainder to environmental effects (12). Hudziak et al. examined the heritability of obsessive-compulsive symptoms in children using the Obsessive-Compulsive Scale of the Child Behavioral Checklist (CBCL) (13). This study included 5707 twin pairs from the Netherlands Twin Registry and the Missouri Twin Study Sample. Across age groups and cultures, $45-61 \%$ of the CBCL OCS was attributed to genetic heritability (13). Taken together these twin studies suggest a significant genetic contribution to the pathogenesis of OCD. 


\section{Family Studies}

Family studies can also be used to determine the heritability of disorders. However, increased rates of transmission within families can be due to either shared genetic or shared environmental factors; thus family studies can provide only circumstantial evidence of heritability of psychiatric disorders (14). They can, however, provide an accurate representation of risk for OCD in relatives and offspring of probands with OCD. Adoption studies would be more definitive in teasing apart genetic and environmental contributions to OCD pathogenesis, but no such studies have been conducted in OCD to date (14).

A meta-analysis of family studies in OCD suggested that first-degree relatives of individuals with OCD were approximately four-fold more likely to develop OCD than relatives of unaffected controls (15). Family studies suggest that early-onset OCD may be particularly heritable form of the disorder, with relatives of early-onset OCD cases being ten-fold more likely than control relatives to develop the disorder (16). Similarly, within adulthood OCD cohorts, earlier age of onset has been associated with increased heritability of symptoms (17-19). First-degree relatives of OCD patients also appear to be at higher risk of developing tic symptoms, body focused repetitive behaviors such as compulsive skin picking and trichotillomania, body dysmorphic disorder, and somatoform disorders, suggesting a shared vulnerability among these conditions $(20,21)$. Some evidence from family studies suggests that the ordering/symmetry symptoms of OCD may be particularly heritable (22).

\section{Genetic Segregation Analyses}

Once the genetic basis of a disorder is established through twin and family based studies, segregation analysis is often utilized to determine specific patterns of genetic transmission of disorders within families. Segregation analysis test the goodness of fit of specific genetic and non-genetic patterns of inheritance compared to the observed patterns (14). Five segregation analyses have been conducted to date in OCD (23-27). While all of these studies are supportive of the genetic transmission of OCD within families, these studies differ with regard to the suggested mode of inheritance.

Initial segregation analyses involving a relatively small number of probands suggested an autosomal dominant transmission pattern for $\operatorname{OCD}(23,27)$. Alsobrook and colleagues conducted a segregation of 96 families that were further phenotyped according to the four principle symptom dimensions of OCD. Their findings were supportive of the genetic transmission of OCD, most specifically, ordering and symmetry symptoms, although no specific model of inheritance could be specified (24). Two more recent segregation analyses $(25,26)$, have suggested gender differences in modes of inheritance with female probands showing greater penetrance and favoring dominant modes of inheritance. Results from segregation analyses in OCD universally support the genetic inheritance of OCD and taken together suggest a complex, polygenetic pattern of inheritance. These studies also highlight that differences in phenotype definition (i.e. OCD symptom dimensions) and recruitment of probands (in terms of gender, early vs. late-onset OCD, tic-related OCD) can have profound effects on the results of OCD genetic studies.

\section{Genetic Linkage Studies}

Genetic linkage studies are used to identify regions that the genome that predispose to disease. Linkage studies are often the first stage in the genetic investigation of a disorder, because they can identify broad areas of the genome that might contain a disease gene, even in the absence of a biological understanding of the underlying pathophysiology (28). To date, three genome-wide linkage studies have been conducted in $\operatorname{OCD}(26,29,30)$. All three 
studies were underpowered and failed to achieve genome-wide significance. However, they have suggested regions of interest that have been studied further in candidate gene studies, as we will further review below.

The first linkage study involved 56 OCD cases from 7 families obtained through childhoodonset OCD probands. The genome scan consisted of 349 microsatellite markers with an average between-marker distance of 11.3 centiMorgan $(\mathrm{cM})$. The maximum LOD score was 2.25 for marker D9S288 on chromosome 9p; this falls below the threshold for genome-wide significance but identified this region as being of potential interest (26). In order to substantiate this finding, $50 \mathrm{sib}$ pairs with one member with OCD were genotyped using microsatellite markers that spanned the 9p24 region. Evidence for suggestive linkage was reported at markers D9S1792 (HLOD=2.26) and D9S1813 (NPL=2.52), which are within $0.5 \mathrm{cM}$ of the original 9p24 linkage signal (31); likewise, pedigree-based association analysis at these markers supported association of polymorphisms at 9p24 with OCD. In both the original genome scan and this confirmatory analysis, the greatest significance was found when the OCD phenotype was construed narrowly (that is, 'definite OCD').

The largest linkage study of OCD to date was conducted by the OCD Collaborative Genetics Study, which recruited from six sites in the USA (30). This study involved 219 OCD families, totaling slightly under 1000 individuals. The genome scan consisted of 386 microsatellite markers with an average between-marker distance of $9 \mathrm{cM}$. Suggestive linkage was demonstrated on chromosomes $3 q 27-28,6 q, 7 p, 1 q$ and 15q. The most suggestive evidence for linkage was achieved when a broad OCD phenotype was used, in contrast to the earlier studies implicating the 9p24 locus. The highest LOD score was demonstrated at D3S1261 and D3S2398 on 3q27-28. No linkage was observed at 9p24. When data in this sample were further examined to determine linkage with compulsive hoarding behaviors, an additional region of suggestive linkage was observed for D14S588 on chromosome $14 \mathrm{q}(32)$.

An additional genome-wide linkage scan was recently completed on 121 individuals from 26 pedigrees with early-onset OCD probands (29). Suggestive linkage (NLOD=2.43) was demonstrated on chromosome 10p15 (29). No evidence of linkage was again reported for the 9 p24 region.

It is noteworthy that these three linkage scans have produced suggestive linkage to a number of different chromosomal regions but have failed to replicate one another. The causes for this are unclear. Certainly all three studies had limited statistical power, rendering them subject to both Type 1 and Type 2 errors. This is particularly true given that none of the three studies achieved the usual criterion for statistically significant genome-wide significance. It is also possible that the underlying genetic heterogeneity of OCD contributed to this discrepancy between studies, and that the studies are finding true linkage peaks but are characterizing somewhat different patient populations. Certainly the linkage peaks found in these various studies merit further exploration.

\section{Candidate Gene Studies}

Candidate gene studies aim to detect an association between a genetic polymorphism of interest and a trait (33). Selection of candidate genes for OCD studies has occurred based on (1) the mechanism of action of effective pharmacological agents for OCD, (2) molecular genetic target suggested by animal models for OCD or (3) proximity to a genetic loci implicated by the linkage studies reviewed above. Initial candidate gene studies focused primarily on genes involved in the serotonin and dopamine neurotransmitter systems. More recently, candidate gene studies have begun to focus on the glutamate system as well. With a 
few notable exceptions, initial promising results from candidate gene studies have failed to replicate in the field (34).

\section{Serotonergic Candidate Genes}

\section{Serotonin Transporter Gene}

The most effective pharmacological treatment for OCD is the use serotonin reuptake inhibitors (SRIs) $(35,36)$. After release from synaptic terminals, serotonin (5-HT) is removed from the synaptic cleft by the serotonin transporter $(5-\mathrm{HTT})$, which is encoded by the $S L C 6 A 4$ gene. SRIs increase brain levels of serotonin by decreasing its reuptake by 5HTT. Based on this observation, polymorphisms in the SLC6A4 have been extensively studied in OCD.

A well-characterized 44-bp insertion/deletion polymorphism (5-HTTLPR) in the promoter region of the $S L C 6 A 4$ gene has been found to influence transcriptional activity of the gene and hence the amount of protein made and presumably efficiency with which 5-HT is removed from the synaptic cleft. In in vitro but not in vivo studies, the long variant (l-allele) of the gene has been demonstrated to be more than twice as efficiently transcribed as the short variant (s-allele) and therefore leads to more efficient reuptake of 5-HT (37-42). Nineteen studies involving 2283 individuals have examined the association between this 5HTTLPR polymorphism and OCD. Despite the positive results of initial association studies, a recent meta-analysis indicated no association between OCD and the 5-HTTLPR polymorphism (43). In post-hoc analysis a significant association between the 1-allele and OCD case status was found when studies were family-based or involved children, leaving open the possibility that the polymorphism may be associated with a subset of OCD cases (43).

A third variant of the 5-HTTLPR gene promoter has been identified more recently. The $\mathrm{L}_{\mathrm{g}}$ allele has a single nucleotide polymorphism compared to the previous characterized long form of the allele $\left(\mathrm{L}_{\mathrm{A}}\right)$. This single nucleotide polymorphism of the $\mathrm{L}_{\mathrm{g}}$ allele results in lower transcriptional activity of the gene, rendering it functionally similar to the s-allele despite having similar length to the $\mathrm{L}_{\mathrm{A}}$ allele (44). This functional polymorphism between the $\mathrm{L}_{\mathrm{A}}$ and $\mathrm{L}_{\mathrm{g}}$ alleles was not distinguished until recent genetic studies (44) and therefore was neglected in the majority of the studies reviewed above (43). This novel polymorphism is a potential source of genetic misclassification in previous candidate gene studies of 5-

HTTLPR. This source of genetic misclassification could dramatically reduce power to detect a significant association at this locus even with a fairly low prevalence. Indeed, the study thsat first characterized the $\mathrm{L}_{\mathrm{g}}$ allele found no association between OCD and 5-HTTLPR when using a biallelic classification (i.e. grouping both subtypes of the L allele together) but demonstrated an association of gain-of-function alleles with OCD when the $\mathrm{L}_{\mathrm{g}}$ alleles were correctly identified (44). More studies that correctly account for the triallelic structure of this locus will be needed to determine whether the negative results studies based on a biallelic classification require revision (43).

\section{Serotonin Receptor Genes}

The serotonin 2A receptor (5-HT2A) has been studied in candidate gene studies of OCD based on the clinical observation that (1) clozapine, an atypical antipsychotic and 5-HT2A receptor antagonist can exacerbate or cause OCD symptoms in schizophrenic patients and (2) chronic use of hallucinogenic drugs such as LSD and psilocin have ameliorated OCD symptoms in some patients (45-47).

In initial case-control association studies, a polymorphism near the promoter region of the 5HT2A gene $(-1438$ A/G) was associated with $\operatorname{OCD}(48,49)$. The first case-control 
demonstrated an association of the A-allele of the $-1438 \mathrm{~A} / \mathrm{G}$ polymorphism with OCD among women but failed to demonstrate an association among the entire 239 subject sample (48). A subsequent study reported an association of the A-allele with OCD in a group of 278 German children (49). Four subsequent case-control studies in Turkish, Jewish, Afrikaner and Mexican samples have failed to demonstrate an association of the $-1438 \mathrm{~A} / \mathrm{G}$ polymorphism with OCD (50-53).

A number of candidate gene studies have also examined the T102C polymorphism in exon 1 of the 5-HT2A gene. This polymorphism is believed to represent a silent mutation in the gene and candidate gene studies for this polymorphism have been consistently negative (50$54)$.

The serotonin $2 \mathrm{C}$ receptor role in $\mathrm{OCD}$ has been implicated by animal studies that have demonstrated compulsive symptoms in 5-HT2C knockout mice and some pharmacological challenge studies that have demonstrated acute exacerbation of OCD symptoms with administration of $\mathrm{m}$-CPP which is a 5-HT2C agonist (55-58). A genetic polymorphism that results in a cysteine to serine substitution at the extracellular $\mathrm{N}$-terminal region of the receptor has been studied in several candidate gene studies but failed to demonstrate any significant association with $\mathrm{OCD}(50,59)$.

The serotonin 1D $\beta$ receptor (also knowon as 5-HT1B) was examined as a candidate gene for OCD after animal studies that suggested that the enhanced release of serotonin in the orbitofrontal cortex upon SRI treatment was mediated through 5-HT1D $\beta$ autoreceptor desensitization (60). Additionally, pharmacological challenges with 5-HT1D agonists such as $\mathrm{m}$-CPP and sumatriptan have been demonstrated to exacerbate OCD symptoms in some studies $(55,57,58)$. Candidate gene studies have focused on a silent $\mathrm{G} 681 \mathrm{C}$ allelic variant of the 5-HT1D $\beta$ receptor gene (34). Although initial family-based association studies in Italian subjects suggested an association of the G-allele with an OCD diagnosis several subsequent studies have failed to replicate this finding (61-64).

\section{Tryptophan Hydroxylase Genes}

Tryptophan hydroxylase (TPH) catalyzes the rate-limiting step in the synthesis of serotonin from tryptophan. There are two isoforms of TPH: TPH1, expressed primarily in the skin, pineal gland and gut; and TPH2, expressed exclusively in the central nervous system. Both TPH isoforms have been studied in candidate gene studies of OCD. Candidate gene studies investigating TPH1 demonstrated no association with OCD $(49,50)$. A family-based association study examined two common single nucleotide polymorphisms (SNPs) of TPH2 in the putative transcriptional control region and in intron 2 of the TPH2 gene in 71 earlyonset OCD trios. Analysis of the single nucleotide polymorphisms (SNPs) rs4570625 and rs4565946, revealed a significant preferential transmission of haplotype G-C to children and adolescents with OCD (65). This association awaits replication.

\section{Dopaminergic Candidate Genes}

Several lines of evidence suggest the importance of the dopaminergic system in OCD: (1) the efficacy of dopamine antagonists for treatment-refractory OCD, (2) functional neuroimaging studies suggesting abnormalities in the dopamine system in OCD and (3) the high comorbidity of OCD with Tourette syndrome.

\section{Dopamine Transporter Genes}

The dopamine transporter gene (SLC6A3) has been studied as a candidate gene in OCD. A 40-bp variable number tandem repeats (VNTR) polymorphism located at the 3' end of the 
gene with unknown functional significance has been studied in OCD. Four separate studies have failed to demonstrate a significant association with $\operatorname{OCD}(50,53,66,67)$.

\section{Dopamine Receptor Genes}

The Dopamine receptor 2 (DRD2) has been studied sparingly in OCD candidate gene studies. Support for the importance of DRD2 in OCD comes from the demonstration of lower DRD2-binding ratios, as measured by SPECT imaging, in the left caudate of subjects with OCD compared to unaffected controls (68). The TaqIA polymorphism, a serine-tocysteine missense mutation occurring in exon 7 of DRD2, was examined in a populationbased case-control study in OCD. No significant association between this polymorphism and OCD was demonstrated in this 220 subject sample (66).

Several studies have examined a single-nucleotide polymorphism in the dopamine receptor 3 (DRD3) that results in a glycine-to-serine amino acid substitution in the third exon. Several studies have failed to demonstrate a significant association with this polymorphism $(52,66$, 69).

The dopamine receptor 4 (DRD4) has been well studied in psychiatric genetics. A polymorphism in exon 3 of the DRD4 gene, within the third cytoplasmic loop of the receptor, consists of a variable number repeats of a 48-bp motif (VNTR); different alleles contain 2-10 repeats. Studies have demonstrated that the seven-repeat allele expresses a receptor with a blunted response, such that at least 3 -fold more dopamine is required to induce a respons, relative to other versions of the receptor. A case-control studies in 245 Ashkenazi Jews demonstrated a significantly lower frequency of A7 alleles in cases than controls (50), but this finding did not withstand statistical correction for multiple hypothesis testing. Another study, which used both family-based and case-control designs, demonstrated a significantly higher frequency of the A2 allele in OCD cases compared to controls but did not find an association with A7 (70). A family-based association study examining 69 early-onset OCD trios demonstrated an increased transmission of both A7 and A2 alleles in OCD cases (71). However, an additional case-control study from South Africa failed to demonstrate a significant association between DRD2 VNTR and OCD (53). This polymorphism merits further study.

\section{Monoamine Oxidase A}

Monoamine oxidase A (MAO-A) degrades epinephrine, norepinephrine, serotonin and dopamine and is the target of monoamine oxidase inhibitor drugs (MAOIs) such as tranylcypromine and phenelzine. Two polymorphisms that have both been shown to affect the activity level of the enzyme have been studied in OCD. A family-based association study of 110 trios demonstrated an association between the low-activity form of the exon $8 \mathrm{~T} / \mathrm{G}$ polymorphism in the MAO-A gene and OCD in males (72). A later study, using both casecontrol and family-based association analyses in a Mexican sample, suggested that the other, high-activity variant was associated with OCD in females (73). A subsequent study within the Afrikaner population showed no evidence of association with OCD, even after stratifying for gender in a different polymorphism that also affects enzyme activity level, T1046C in exon 14 (53). The potential contribution of MAO-A polymorphisms, in both males and females, requires further elucidation.

\section{Catechol-O-methyltransferace Gene}

Catechol-O-methyltransferace (COMT) is also involved in the inactivation of catecholamines (norepinephrine, epinephrine and dopamine), by methylation rather than oxidation; COMT is thought to be relatively more important for terminating dopamine neurotransmission in the frontal lobes, while MAO has a larger role in subcortical structures. 
A SNP encoding for a valine-to-methionine substitution at codon 158 (val158met) has been demonstrated to affect the activity of the enzyme (74). Despite several initially promising results, a meta-analysis of 7 studies involving 413 OCD cases and 865 controls found no evidence of association between the COMT val158met polymorphism and OCD (75). A subsequent meta-analysis, involving the addition of 1 case-control study with 414 additional samples, suggested that there may indeed be an association of the COMT met158 allele and OCD, but only in males (76). As in the case of MAO-A, further investigations are needed to better elucidate this intriguing potential sex-specific effect.

\section{Glutamatergic Candidate Genes}

There has been significant interest recently in the possible role of perturbations of glutamatergic neurotransmission in $\mathrm{OCD}(77)$. While early evidence for such a role came from neuroimaging studies (78) and small open-label pharmacological trials $(79,80)$, this view gained credibility and broader interest with the replicated association in the past few years of glutamatergic genes with OCD.

\section{The neuronal glutamate transporter EAAT3}

As reviewed above, the first genomic linkage scan performed in OCD, and a follow-up replication study, suggested linkage of OCD risk with polymorphisms at 9 p24 $(26,31)$. The identified region contained many known and predicted genes, including the primary neuronal glutamate transporter, Slc1A1 (also EAAT3, EAAC1). Further suggestive evidence for an OCD susceptibility gene on chromomsome 9 derived from the description of a patient with both OCD and Tourette syndrome with a monosomy of chromosome 9 (81).

In 2006, a pair of well-powered association studies lent credence to SLC1A1 as an OCD risk gene. An early association study from Hanna's group showed no association with two markers in two SNPs in intron 3 of the SLC1A1 gene (82); but a larger family-based association study using more markers revealed significant association between OCD and two SNPs in the 3' region of the gene (83). These authors also described a multigenerational pedigree in which the disorder was associated with a small deletion in the 3' flanking region of Slc1A1; while the functional consequence of this deletion remains unclear, it lends further credence to the conclusion that dysregulation of Slc1A1 may contribute to risk for OCD (83). Simultaneously, Arnold and colleagues published an independent family-based association study examining 9 SNPs spanning the SLC1A1 locus. They found two markers, within the same haplotype block (albeit one distinct from that found in the previous study), significantly associated with transmission of OCD (84).

Interestingly, both of these studies found the association between SLC1A1 genotype and transmission of OCD to be significant for male probands but not female probands $(83,84)$. There was also a suggestion that the association was strongest when probands had earlyonset OCD. Dickel and colleagues ascertained specifically for early-onset OCD (83) (as had the original genome scan that identified 9p24 as a region of interest; (26)). Arnold and colleagues did not specifically recruit subjects with early-onset disease; but a secondary analysis of their data suggested association only within the early onset group (84; this finding did not', however', survive correction for multiple comparisons). These observations are intriguing in light of the fact that early-onset OCD is thought to be genetically distinct from adult-onset disease (85) and to be more heritable (17-19). (Indeed, this higher heritability motivated the focus on pediatric-onset probands in several studies; $(26,83)$.)

Association of SLC1A1 with OCD risk has now been replicated in a number of other studies. Stewart and colleagues genotyped 66 OCD probands and their families at 18 SNPs spanning the 3' end of the Slc1A1 gene (86). They found association of OCD risk with the 
same 3' haplotype reported by Dickel et al (83), distinct from but close to that reported by Arnold and colleagues (84). Association was again more significant in males. Interestingly, the pattern of overtransmission of a specific haplotype in this replication study was opposite that reported in the original association; this has been interpreted as evidence that the tested SNPs are not themselves causative of the increased risk for OCD but rather are in linkage disequilibrium with a causative SNP (86). Despite these differences in the studies, the replication of association at the same locus stands in contrast to the history of nonreplication that has plagued many earlier genetic findings in OCD (34).

More recent studies have followed this pattern: while failing to replicate overtransmission of precisely the same haplotype as was identified in the original studies $(83,84)$, they have by and large continued to report association of OCD risk with polymorphisms at the SLC1A1 locus. Shugart and colleagues genotyped 13 SNPs spanning the Slc1A1 gene in members of 378 families with OCD probands, using somewhat different methodology and more extended pedigrees than earlier studies the locus. They did not replicate association of OCD risk with the specific SNPs found in earlier studies, but they did find highly significant association of OCD risk with a distinct SNP, $7.5 \mathrm{~kb}$ outside the SLC1A1 gene. They hypothesize that, although it is beyond the gene proper, this SNP (or another causative SNP in linkage disequilibrium with it) may disrupts EAAT3 expression or function (87). Further evidence supporting a role for SLC1A1 in OCD comes from a recent case-control study of 325 OCD probands and 662 controls, in which specific SLC1A1 haplotypes were again found to be associated with OCD risk (88). This latter study did not find increased association in males and provided evidence for causative polymorphisms both in the 3' region of the gene, as suggested by previous family-based studies, and closer to the 5' end; the authors tentatively interpret this as evidence for multiple causative polymorphisms (88).

These association studies have produced increasing confidence that polymorphisms at the SLC1A1 locus contribute to OCD risk; but they have shed little light on the causative polymorphism. Two recent studies have sought to elucidate this issue. Wang and colleagues screened the coding regions of SLC1A1 from 378 patients with OCD, and controls, for potentially functional polymorphisms. They found several synonymous substitution mutations in OCD probands and one nonsynonymous mutation, whose functional significance remains unclear (87).

Wendland and colleagues screened known SNPs at the Slc1A1 locus, including all those associated with the OCD phenotype in earlier studies, for their correlation with Slc1A1 expression in lymphoblasts and in postmortem brain tissue (from normal controls or patients with other, non-OCD psychiatric conditions). They found that three polymorphisms predicted Slc1A1 expression in immortalized lymphoblasts, and that SNP rs301430 predicted expression in brain tissue. Furthermore, in an in vitro assay this SNP was found to influence expression of a reporter gene (88). This SNP was associated with OCD risk in two of the previous genetic association studies $(83,86)$.

These exciting data provide the clearest evidence to date for a direct connection between known polymorphisms at the Slc1A1 locus and the function of the gene. It is to be hoped that further investigations along these lines will lead to hypotheses as to how the gene is perturbed in OCD, and how this perturbation leads to the circuit dysfunction and symptomatology of the disorder.

\section{The glutamatergic synapse: SAPAP and glutamtae receptor genes}

The glutamatergic synapse is a complicated and highly regulated structure. Postsynaptically, several subtypes of glutamate receptor are organized spatially by direct and indirect interactions with the cytoskeleton of the postsynaptic cell. In particular, glutamate receptors 
of the NMDA and AMPA classes interact with the meshwork of proteins that makes up the postsynaptic density (PSD) and are therefore localized on dendritic spines. Physiological or pathological postsynaptic changes in glutamatergic neurotransmission can thus be produced by changes in the receptors themselves or in the PSD in which they are embedded.

Significant attention has focused in recent years on a critical component of the PSD, termed 'synapse associated protein associated protein', or SAPAP. In particular, SAPAP3, which is highly expressed in the basal ganglia circuitry implicated in OCD, has emerged as a potential OCD candidate gene. In contrast to the case of SLC1A1, in which a candidate gene emerged as a result of gene linkage scans and subsequent targeted association studies, interest in SAPAP3 derives from studies in mice. Feng and colleagues found knockout of SAPAP3 in mice to produce a behavioral phenotype reminiscent of important aspects of OCD, including anxiety and compulsive grooming (89). Importantly, both of these phenotypes reversed with treatment with the selective serotonin reuptake inhibitor fluoxetine, which is an established treatment for OCD. Furthermore, the knockout produced dysregulation of glutamatergic synaptic transmission in the striatum; again, such a dysregulation has been suggested to occur in $\operatorname{OCD}(77,78)$.

It remains unclear whether these mice are best characterized as exhibiting OCD-like behaviors, or whether they might be better described as recapitulating trichotillomania or some other disorder of repetitive, compulsive behavior and anxiety. Indeed, interpretative difficulties of this sort inevitably accompany any attempt to model psychiatric conditions, with their complex and inevitably subjective symptomatology, in animals. Despite this, several groups have begun to investigate SAPAP3 in OCD, and grooming disorders, in humans.

A study from the Obsessive-Compulsive Disorder Collaborative investigated this question in 383 families with OCD; $32 \%$ of the subjects had trichotillomania or another grooming disorder. Several SNPs within the SAPAP3 gene were significantly associated with a grooming disorder, using a family-based association test. No SAPAP3 SNPs were associated with OCD independent of grooming disorders (87).

More recently, a group based at Miami, the NIH and Duke described complete sequencing of SAPAP3 in patients with OCD, TTM, or both, and a group of normal controls. Seven novel mutations, one of which was seen twice, were identified in patients with OCD and/or $\operatorname{TTM}(4.2 \%)$, while only two mutations were found in control subjects $(1.1 \% ; 90)$. While the functional significance of these mutations is unclear, and in silico analysis suggested that most of them are likely to be benign, the authors suggest that an accumulated load of minor mutations may have the aggregate effect of increasing risk for OCD and/or grooming disorders (90).

The evidence for a role for SAPAP3 in human disease remains very preliminary; it is perhaps stronger for grooming disorders than for OCD itself. Regardless, this gene remains an intriguing candidate for future studies; and the OCD-like phenotype of the knockout mouse (89) has created new interest in modeling OCD-like behaviors in animals through manipulations of glutamate-related genes.

Candidate gene studies have examined several other glutamate-related genes as potential risk alleles for OCD. Two studies have examined the potential contribution of the NMDA receptor subunit GRIN2B to OCD. Arnold and colleagues examined SNPs in the GRIN2B gene in 178 adult OCD patients and 211 unaffected family member controls; they reported association of a single SNP with OCD transmission (91). More recently, an association was observed between GRIN2B alleles and the concentration of glutamate and related molecules, as measured by magnetic resonance spectroscopy (MRS), in the anterior 
cingulate cortex (92); MRS has previously revealed perturbation of glutamate and related molecules in this region in patients with OCD (93). While the association of GRIN2B genotype with OCD risk remains to be replicated and clarified, studies of this sort demonstrate a new approach to linking genetics, neurochemical endophenotypes, and psychiatric diagnosis to better elucidate both genetics and pathophysiology.

One early study examined the kainate-class glutamate receptors GRIK2 and GRIK3 in 156 OCD cases with matched controls as well as 124 parent-offspring trios. Association between SNPs in these genes and the OCD phenotype was by and large negative, though nominally significant association was reported with a single SNP in GRIK2 (94). The potential association of OCD with GRIK2 has not been further examined to date.

\section{Other Candidate Genes}

\section{Brain Derived Neurotrophic Growth Factor}

Brain-derived neurotrophic factor $(B D N F)$ is important in neuronal survival, maturation, and plasticity $(44,95)$. The Val66Met polymorphism in the BDNF gene has been extensively studied in various psychiatric conditions. The polymorphism influences BDNF processing and its activity-dependent release from neurons. It has been associated in humans with hippocampal size, cognitive function, and mood and anxiety phenotypes. $(44,96)$. Similarly, a mouse in which the BDNF gene has been mutated to recapitulate the human Met allele exhibits increased anxiety-related behaviors (97)

Ths polymorphism is therefore a natural candidate for OCD, and other anxiety disorders. Initial case-control association studies suggested, in post-hoc analysis, that the Val66Met polymorphism was associated with increased OCD risk in the subgroup with early-onset disease (98). However, several subsequent candidate gene studies in early-onset or all OCD cases failed to replicate this association (99-103).

\section{Oligodendrocyte Lineage Transcription Factor 2}

Oligodendrocyte lineage transcription factor $2(O L I G 2)$ is an essential regulator in the development of oligodendrocytes, the cells that myelinate axons in the central nervous system. The $O L I G 2$ gene is highly expressed in the amygdala, thalamus, and caudate nuclei -brain regions implicated in OCD $(104,105)$. Furthermore, white matter abnormaltiies have been demonstrated in OCD by diffusion tensor imaging (DTI) $(106,107)$. In a familybased association study of 57 early-onset OCD trios, 3 SNPs (rs762178, rs 1059004 and rs9653711) within the OLIG2 gene were associated with OCD (105). The OLIG2 gene represents a promising candidate gene in early-onset OCD, however, the results of this study have yet to be replicated.

\section{Immune-related genes}

It has been hypothesized that some cases of OCD may be related to autoimmune dysfunction. In particular, some cases of episodic OCD symptoms in the pediatric population appear to be associated with an autoimmune reaction to Group A streptococcal infection; this syndrome, whose details remain somewhat controversial, has been named "pediatric autoimmune neuropsychiatric disorder associated with Streptococcus," or PANDAS (108). The existence of this syndrome, and the possibility that a broader subset of OCD cases may be attributable to perturbed immune function, has motivated investigation of candidate immunological genes in OCD in a few association studies.

Myelin oligodendrocyte glycoprotein (MOG) is a key component of the complement cascade. Four polymorphisms in the MOG gene, a dinucleotide CA repeat (MOG2), a 
tetranucleotide TAAA repeat (MOG4), and 2 intronic single nucleotide polymorphisms, C1334T and C10991T, were investigated for the possibility of association with OCD using 160 nuclear families with OCD probands (91). Analysis revealed a significantly increased transmission of allele 2 of MOG4 to affected probands. This association remains to be replicated.

Tumor necrosis factor a (TNFA) is a proinflammatory cytokine involved in rheumatic fever and other autoimmune diseases (109). Polymorphisms in the promoter region of the TNFA gene have been associated with rheumatic fever. Obsessive-compulsive symptoms are common in individuals with rheumatic fever, and OCD is overrepresented in the relatives of individuals with rheumatic fever (110). The $-308 \mathrm{G} / \mathrm{A}$ polymorphism in the TNFA gene promoter is believed to affect transcription of the gene (111). An initial examination of this polymorphism in a Canadian sample failed to detect any significant association with OCD (112). However, a subsequent study from Brazil, examining both the $-308 \mathrm{G} / \mathrm{A}$ polymorphism and a separate $-238 \mathrm{G} / \mathrm{A}$ polymorphism in 111 patients and 250 controls, found significant associations with both polymorphisms. This candidate gene clearly merits further investigation (113).

\section{CONCLUSIONS}

Genetic studies of OCD have taught us several important points about the disorder over the past two decades. Twin and family studies demonstrate that OCD has a significant hereditary component, although and environmental factors appear equally or more important in most studies. Genetic linkage studies have demonstrated that OCD is a complex genetic disorder that likely has many susceptibility genes, each of small effect. Of the three genomewide linkage scans published to date, none has identified a locus that reached the statistical threshold for genome-wide significance; and the three have provided suggestive evidence of linkage to distinct genomic regions. The likelihood of finding susceptibility genes that are both common and of large effect is becoming exceedingly small.

\section{Association studies and failures of replication}

Despite the publication of nearly 100 candidate gene association studies from over 2 dozen groups of investigators over the past 2 decades, we have few convincing, replicated associations of specific genetic polymorphisms with OCD risk. Initial positive studies followed by repeated failures to replicate and negative findings upon meta-analysis have been the norm, as summarized in multiple specific cases above. Frustration and confusion has developed over the frequency with which initial positive candidate gene studies in OCD and other psychiatric conditions are not replicated (114).

There are several possible explanations for this difficulty in replication. Broadly speaking, it can derive either from false-positive findings (Type 1 error) in initial studies, from falsenegative findings (Type 2 error) in replication studies, or from complexities in the genetics of the disorder that render replication challenging even if the initial positive finding is valid. Going forward, investigations of the genetics of OCD, as of all complex disorders, must grapple with these sources of complexity.

Several characteristics of individual candidate gene association studies may contribute to false-positive results. (1) Statistically, false positive results may result from inadequate control for multiple hypothesis testing; this is particularly likely to be problematic when a single, valuable repository of well-characterized DNAs is tested, in separate studies, for multiple candidate genes. (2) Publication bias can magnify this effect; statistically significant findings, even in post-hoc analyses of subgroups, are more likely to be published than negative association findings. (3) Genotyping error can also contribute; while it is 
perhaps more likely to contribute to false negative results, genotyping error can also lead to false positive results (114). Case-control studies are particularly prone to false-positive error when there are batch differences in error rates and case and control samples are treated differently. Family-based association studies are also inherently biased towards falsepositive results as error rate increases. (4) False positive results can derive from population stratification - the presence of systematic differences in allele frequency between subpopulations due to differences in ancestry. If cases are not optimally matched to controls, by sex and ancestry (as measured either by genetic criteria or by surrogate markers), systematic differences may emerge that are not actually related to the condition of interest.

Failure to replicate a valid initial finding can derive from false-negative error in replication studies, which can derive from any of several sources. (1) Inadequate sample size and statistical power can readily lead to a false negative result, especially when rigorous statistical criteria are (appropriately) employed. (2) Genotyping error can easily lead to a false negative result; traditionally, very few journals have required reporting of genotyping error rate. Genotyping error rates, even in well run laboratories are not uncommon (often 1$3 \%$ in the case of SNPs) (115). High genotyping error rates can greatly reduce the power of genetic studies. A $1 \%$ increase in error rates might require a 2-8\% increase in sample size to maintain consistent statistical power (116).

Perhaps most interestingly - failures to replicate a valid initial finding can derive from the complexity of the disorder itself. Population stratification between studies, rather than within them, may contribute to such a phenomenon, especially as candidate gene studies have been performed by groups around the world, on widely different ethnic populations. Since allele frequencies inevitably differ at many loci in ancestrally distinct populations, and since the effect size of an OCD susceptibility gene may be moderated by its interactions with alleles at other genetic loci, the effect size of any given candidate gene may differ substantially between different populations and hence between different studies. If so, a positive association finding in one population, in which the effect size of the candidate polymorphism is large due to such epistatic interactions, may be hard to replicate in a distinct population in which the effect size is smaller.

Finally, the heterogeneity of the disorder itself may contribute to differenes between studies. OCD is a clinically complex disorder, and two patients with the diagnosis can have completely non-overlapping symptomatology (117). There has been substantial interest recently in characterizing overlapping but distinct dimensions of symptomatology (3). It may be that risk genes are associated with one dimension more than others; indeed, there is evidence that this is the case, at least for hoarding symptoms (118). If the clinical characteristics of the patients in a replication study differs substantially from those of the patients in the original study, due to differences in ascertainment or the environment from which they are drawn, the effect size of a given risk allele may again be affected.

\section{Positive candidate gene associations}

Despite these challenges and the multiple failures to replicate candidate gene association studies, at least one reasonably convincing susceptibility gene for OCD has been identified. SLC1A1, which encodes the neuronal glutamate transporter EAAT3 (also EAAC1), falls under the linkage peak on chromosome 9 indentified in the first genome scan (26). Its plausibility as a functional candidate gene derives from the increasing evidence that glutamate dysregulation may contribute to the pathophysiology of OCD (77). SNPs in or adjacent to this gene, primarily at its 3 ' end, have now been associated with OCD in five separate association studies $(83,84,86-88)$. 
As summarized above, other associations have been less convincing. Replication has yet to be attempted for several candidate genes, such as OLIG2 (105), and initial positive findings must therefore be interpreted with caution. Secondary analysis and meta-analyses have suggested association of some candidates with specific subpopulations, but confirmatory studies in which such subpopulations were identified in the primary analysis have not yet been performed. Clarity on whether any of the other candidate genes described above represent bona fide OCD risk genes must await further study.

\section{Future directions: increasing power and reliability}

The sources of failures to replicate listed above lead to clear ways in which the genetics of OCD can be clarified in future studies, all of which are being pursued by investigators in the field.

Increasing the sample size and power of future genetic studies is imperative, as it is clear that OCD is a multifactorial disorder determined by environmental influences as well as many susceptibility genes of small effect (14). Single-site studies are typically not large enough to detect susceptibility genes of small effect. Towards this end, two collaborative multi-site efforts for the elucidation of the genetics of OCD have been established. The OCD Genetics Collaborative collects samples from 6 US sites (Brown University, Columbia University/New York State Psychiatric Institute, Johns Hopkins University, Massachusetts General Hospital, University of California at Los Angeles, and the National Institute of Mental Health). This 6-site collaboration effort has studied several hundred familes with OCD and has produced a number of important findings, as summarized above (19, 30, 32, 87).. A more recently formed group, the Obsessive Compulsive Foundation Genetics Collaborative is a collaboration of over 50 investigators from more than 20 sites in North America, South America, Europe and Africa. Established in 2002, the Collaborative has been able to pool over 3000 existing samples together to run the first genome-wide association study in OCD. The results of this study are eagerly anticipated and will hopefully significantly further our understanding of the genetics of OCD. Such collaborative efforts will need to be maintained in the future in order provide the necessary power for replication of initial findings and for ongoing investigations of adequate power to provide reliable results.

Improved selection of cases and controls will also improve the reliability of genetic studies. Family-based association studies, which collect trios of probands and their immediate relatives, adequately account for most of problems with control selection, since a ghostcontrol for each case can be created from the non-transmitted alleles of each parent (33). However, the advantages associated with this experimental design are partially counteracted by the increased difficulty associated with recruiting trios for genetic studies. In case-control genetic association studies, the use of genetic markers can now ensure proper matching by ethnicity and account for issues of population stratification (119). However, the current selection of cases for OCD genetics studies primarily involves recruitment from tertiary academic centers engaged in OCD research. Subjects reaching tertiary academic centers often differ in intelligence, socioeconomic status, responsive to treatment and impairment compared to population-based samples of OCD..

Refinement of how OCD cases are ascertained and described at the phenotypic level may increase the power of genetic studies. It may prove more fruitful to seek genetic contributors to obsessionality as a continuous trait, rather than clinical OCD as a dichotomous factor. This would permit the inclusion of individuals with symptoms not severe enough to produce impairment or merit clinical attention. Several studies have suggested a higher heritability when OCD is construed broadly in this way (i.e. not requiring the impairment that is necessary for a clinical diagnosis) $(12,13)$. 
Enriching the phenotype of OCD cases for genetic studies to increase homogeneity and enhance heritability in samples may be further beneficial to OCD genetic studies. Clinical characteristics such as age of onset and comorbid conditions such as tics may identify more homogenous subpopulations on which to do genetic analyses. Indeed, OCD with comorbid tics has been shown to have a different longitudinal course and differential pharmacological response relative to $\mathrm{OCD}$ without tics, suggesting that it may represent a distinct subsyndrome (120-122). Similarly, insofar as different symptomatic types of OCD represent distinct (though overlapping) dimensions of pathology, increasing homogeneity by focusing on specific symptomatic groups such as hoarding or washing may enhance our ability to identify causative polymorphisms (3).

Advancing genetic technologies will allow us to conduct larger, more powerful studies examining the genetics of OCD. Larger, collaborative studies are crucial given that OCD is a complex genetic trait with multiple susceptibility genes of small effect. Combining these technologies with sound experimental techniques from the field of epidemiology such as proper selection of controls and correction for multiple hypothesis testing will aid in the advancement. Improved characterization of the phenotype of OCD and the use of endophenotypes in genetic studies will provide further help in the effort.

\section{Acknowledgments}

The authors acknowledge the National Institute of Mental Health support of the Yale Child Study Center Research Training Program (MHB), the National Institutes of Health Loan Repayment Program (MHB), NIMH K08 81190 (CP), the support of the Tourette's Syndrome Association (CP), the Doris Duke Charitable Foundation (CP), CTSA Grant UL1 RR024139 from the National Center for Research Resources (CP), the Trichotillomania Learning Center (MHB), the APIRE/Eli Lilly Psychiatric Research Fellowship (MHB), the AACAP/ Eli Lilly Pilot Research Award (MHB), and NARSAD (MHB, CP).

\section{References}

1. Karno M, Golding JM, Sorenson SB, Burnam MA. The epidemiology of obsessive-compulsive disorder in five US communities. Arch Gen Psychiatry. 1988 Dec; 45(12):1094-1099. [PubMed: 3264144]

2. Kessler RC, Berglund P, Demler O, Jin R, Merikangas KR, Walters EE. Lifetime prevalence and age-of-onset distributions of DSM-IV disorders in the National Comorbidity Survey Replication. Arch Gen Psychiatry. 2005 Jun; 62(6):593-602. [PubMed: 15939837]

3. Bloch MH, Landeros-Weisenberger A, Rosario MC, Pittenger C, Leckman JF. Meta-analysis of the symptom structure of obsessive-compulsive disorder. Am J Psychiatry. 2008 Dec; 165(12):15321542. [PubMed: 18923068]

4. Geller DA, Biederman J, Jones J, Shapiro S, Schwartz S, Park KS. Obsessive-compulsive disorder in children and adolescents: a review. Harv Rev Psychiatry. 1998 Jan-Feb;5(5):260-273. [PubMed: 9493948]

5. Rosario-Campos MC, Leckman JF, Mercadante MT, Shavitt RG, Prado HS, Sada P, et al. Adults with early-onset obsessive-compulsive disorder. Am J Psychiatry. 2001 Nov; 158(11):1899-1903. [PubMed: 11691698]

6. Treatment of obsessive-compulsive disorder. The Expert Consensus Panel for obsessive-compulsive disorde. J Clin Psychiatry. 1997; 58(Suppl 4):2-72. [PubMed: 9183300]

7. Pallanti S, Hollander E, Goodman WK. A qualitative analysis of nonresponse: management of treatment-refractory obsessive-compulsive disorder. J Clin Psychiatry. 2004; 65(Suppl 14):6-10. [PubMed: 15554782]

8. van Grootheest DS, Cath DC, Beekman AT, Boomsma DI. Twin studies on obsessive-compulsive disorder: a review. Twin Res Hum Genet. 2005 Oct; 8(5):450-458. [PubMed: 16212834]

9. Carey, G.; Gottesman, II. Twin and family studies of anxiety, phobic, and obsessive disorders. In: Klein, DF.; Rabkin, J., editors. Anxiety: New research and changing concepts. New York: Raven Press; 1981. p. 117-136. 
10. Skre I, Onstad S, Torgersen S, Lygren S, Kringlen E. A twin study of DSM-III-R anxiety disorders. Acta Psychiatr Scand. 1993 Aug; 88(2):85-92. [PubMed: 8213211]

11. Torgersen S. Genetic factors in anxiety disorders. Arch Gen Psychiatry. 1983 Oct; 40(10):10851089. [PubMed: 6625857]

12. Jonnal AH, Gardner CO, Prescott CA, Kendler KS. Obsessive and compulsive symptoms in a general population sample of female twins. Am J Med Genet. 2000 Dec 4; 96(6):791-796. [PubMed: 11121183]

13. Hudziak JJ, Van Beijsterveldt CE, Althoff RR, Stanger C, Rettew DC, Nelson EC, et al. Genetic and environmental contributions to the Child Behavior Checklist Obsessive-Compulsive Scale: a cross-cultural twin study. Arch Gen Psychiatry. 2004 Jun; 61(6):608-616. [PubMed: 15184240]

14. Pauls DL. The genetics of obsessive compulsive disorder: a review of the evidence. Am J Med Genet C Semin Med Genet. 2008 May 15; 148C(2):133-139. [PubMed: 18412099]

15. Hettema JM, Neale MC, Kendler KS. A review and meta-analysis of the genetic epidemiology of anxiety disorders. Am J Psychiatry. 2001 Oct; 158(10):1568-1578. [PubMed: 11578982]

16. do Rosario-Campos MC, Leckman JF, Curi M, Quatrano S, Katsovitch L, Miguel EC, et al. A family study of early-onset obsessive-compulsive disorder. Am J Med Genet B Neuropsychiatr Genet. 2005 Jul 5; 136B(1):92-97. [PubMed: 15892140]

17. Bellodi L, Sciuto G, Diaferia G, Ronchi P, Smeraldi E. Psychiatric disorders in the families of patients with obsessive-compulsive disorder. Psychiatry Res. 1992 May; 42(2):111-120. [PubMed: 1631248]

18. Pauls DL, Alsobrook JP 2nd, Goodman W, Rasmussen S, Leckman JF. A family study of obsessive-compulsive disorder. Am J Psychiatry. 1995 Jan; 152(1):76-84. [PubMed: 7802125]

19. Nestadt G, Samuels J, Riddle M, Bienvenu OJ 3rd, Liang KY, LaBuda M, et al. A family study of obsessive-compulsive disorder. Arch Gen Psychiatry. 2000 Apr; 57(4):358-363. [PubMed: 10768697]

20. Bienvenu OJ, Samuels JF, Riddle MA, Hoehn-Saric R, Liang KY, Cullen BA, et al. The relationship of obsessive-compulsive disorder to possible spectrum disorders: results from a family study. Biol Psychiatry. 2000 Aug 15; 48(4):287-293. [PubMed: 10960159]

21. Grados MA, Riddle MA, Samuels JF, Liang KY, Hoehn-Saric R, Bienvenu OJ, et al. The familial phenotype of obsessive-compulsive disorder in relation to tic disorders: the Hopkins OCD family study. Biol Psychiatry. 2001 Oct 15; 50(8):559-565. [PubMed: 11690590]

22. Hanna GL, Himle JA, Curtis GC, Gillespie BW. A family study of obsessive-compulsive disorder with pediatric probands. Am J Med Genet B Neuropsychiatr Genet. 2005 Apr 5; 134B(1):13-19. [PubMed: 15635694]

23. Cavallini MC, Pasquale L, Bellodi L, Smeraldi E. Complex segregation analysis for obsessive compulsive disorder and related disorders. Am J Med Genet. 1999 Feb 5; 88(1):38-43. [PubMed: 10050965]

24. Alsobrook IJ, Leckman JF, Goodman WK, Rasmussen SA, Pauls DL. Segregation analysis of obsessive-compulsive disorder using symptom-based factor scores. Am J Med Genet. 1999 Dec 15; 88(6):669-675. [PubMed: 10581488]

25. Nestadt G, Lan T, Samuels J, Riddle M, Bienvenu OJ 3rd, Liang KY, et al. Complex segregation analysis provides compelling evidence for a major gene underlying obsessive-compulsive disorder and for heterogeneity by sex. Am J Hum Genet. 2000 Dec; 67(6):1611-1616. [PubMed: 11058433]

26. Hanna GL, Veenstra-VanderWeele J, Cox NJ, Boehnke M, Himle JA, Curtis GC, et al. Genomewide linkage analysis of families with obsessive-compulsive disorder ascertained through pediatric probands. Am J Med Genet. 2002 Jul 8; 114(5):541-552. [PubMed: 12116192]

27. Nicolini H, Hanna GL, L B, Schwartz JM, Weissbecker K, Spence MA. Segregation analysis of obsessive compulsive disorders. Preliminary results. Ursus Medicus. 1991; 1:25-28.

28. Dawn Teare M, Barrett JH. Genetic linkage studies. Lancet. 2005 Sep 17-23; 366(9490):10361044. [PubMed: 16168786]

29. Hanna GL, Veenstra-Vanderweele J, Cox NJ, Van Etten M, Fischer DJ, Himle JA, et al. Evidence for a susceptibility locus on chromosome 10p15 in early-onset obsessive-compulsive disorder. Biol Psychiatry. 2007 Oct 15; 62(8):856-862. [PubMed: 17544380] 
30. Shugart YY, Samuels J, Willour VL, Grados MA, Greenberg BD, Knowles JA, et al. Genomewide linkage scan for obsessive-compulsive disorder: evidence for susceptibility loci on chromosomes 3q, 7p, 1q, 15q, and 6q. Mol Psychiatry. 2006 Aug; 11(8):763-770. [PubMed: 16755275]

31. Willour VL, Yao Shugart Y, Samuels J, Grados M, Cullen B, Bienvenu OJ 3rd, et al. Replication study supports evidence for linkage to 9 p24 in obsessive-compulsive disorder. Am J Hum Genet. 2004 Sep; 75(3):508-513. [PubMed: 15272418]

32. Samuels JF, Bienvenu OJ 3rd, Pinto A, Fyer AJ, McCracken JT, Rauch SL, et al. Hoarding in obsessive-compulsive disorder: results from the OCD Collaborative Genetics Study. Behav Res Ther. 2007 Apr; 45(4):673-686. [PubMed: 16824483]

33. Cordell HJ, Clayton DG. Genetic association studies. Lancet. 2005 Sep 24-30; 366(9491):11211131. [PubMed: 16182901]

34. Hemmings SM, Stein DJ. The current status of association studies in obsessive-compulsive disorder. Psychiatr Clin North Am. 2006 Jun; 29(2):411-444. [PubMed: 16650716]

35. Bloch MH, McGuire J, Landeros-Weisenberger A, Leckman JF, Pittenger C. Meta-analysis of the dose-response relationship of SSRI in obsessive-compulsive disorder. Mol Psychiatry. 2009 May 26.

36. Soomro GM, Altman D, Rajagopal S, Oakley-Browne M. Selective serotonin re-uptake inhibitors (SSRIs) versus placebo for obsessive compulsive disorder (OCD). Cochrane Database Syst Rev. 2008; (1) CD001765.

37. Cavallini MC, Di Bella D, Siliprandi F, Malchiodi F, Bellodi L. Exploratory factor analysis of obsessive-compulsive patients and association with 5-HTTLPR polymorphism. Am J Med Genet. 2002 Apr 8; 114(3):347-353. [PubMed: 11920862]

38. Heils A, Teufel A, Petri S, Stober G, Riederer P, Bengel D, et al. Allelic variation of human serotonin transporter gene expression. J Neurochem. 1996 Jun; 66(6):2621-2624. [PubMed: 8632190]

39. Lesch KP, Bengel D, Heils A, Sabol SZ, Greenberg BD, Petri S, et al. Association of anxietyrelated traits with a polymorphism in the serotonin transporter gene regulatory region. Science. 1996 Nov 29; 274(5292):1527-1531. [PubMed: 8929413]

40. Willeit M, Stastny J, Pirker W, Praschak-Rieder N, Neumeister A, Asenbaum S, et al. No evidence for in vivo regulation of midbrain serotonin transporter availability by serotonin transporter promoter gene polymorphism. Biol Psychiatry. 2001 Jul 1; 50(1):8-12. [PubMed: 11457418]

41. Shioe K, Ichimiya T, Suhara T, Takano A, Sudo Y, Yasuno F, et al. No association between genotype of the promoter region of serotonin transporter gene and serotonin transporter binding in human brain measured by PET. Synapse. 2003 Jun 15; 48(4):184-188. [PubMed: 12687637]

42. Parsey RV, Hastings RS, Oquendo MA, Hu X, Goldman D, Huang YY, et al. Effect of a triallelic functional polymorphism of the serotonin-transporter-linked promoter region on expression of serotonin transporter in the human brain. Am J Psychiatry. 2006 Jan; 163(1):48-51. [PubMed: 16390888]

43. Bloch MH, Landeros-Weisenberger A, Sen S, Dombrowski P, Kelmendi B, Coric V, et al. Association of the serotonin transporter polymorphism and obsessive-compulsive disorder: systematic review. Am J Med Genet B Neuropsychiatr Genet. 2008 Sep 5; 147B(6):850-858. [PubMed: 18186076]

44. Hu XZ, Lipsky RH, Zhu G, Akhtar LA, Taubman J, Greenberg BD, et al. Serotonin transporter promoter gain-of-function genotypes are linked to obsessive-compulsive disorder. Am J Hum Genet. 2006 May; 78(5):815-826. [PubMed: 16642437]

45. Leonard HL, Rapoport JL. Relief of obsessive-compulsive symptoms by LSD and psilocin. Am J Psychiatry. 1987 Sep; 144(9):1239-1240. [PubMed: 3631327]

46. Baker RW, Chengappa KN, Baird JW, Steingard S, Christ MA, Schooler NR. Emergence of obsessive compulsive symptoms during treatment with clozapine. J Clin Psychiatry. 1992 Dec; 53(12):439-442. [PubMed: 1487472]

47. Patil VJ. Development of transient obsessive-compulsive symptoms during treatment with clozapine. Am J Psychiatry. 1992 Feb.149(2):272. [PubMed: 1734752] 
48. Enoch MA, Greenberg BD, Murphy DL, Goldman D. Sexually dimorphic relationship of a 5HT2A promoter polymorphism with obsessive-compulsive disorder. Biol Psychiatry. 2001 Feb 15; 49(4):385-388. [PubMed: 11239910]

49. Walitza S, Wewetzer C, Warnke A, Gerlach M, Geller F, Gerber G, et al. 5-HT2A promoter polymorphism -1438G/A in children and adolescents with obsessive-compulsive disorders. Mol Psychiatry. 2002; 7(10):1054-1057. [PubMed: 12476319]

50. Frisch A, Michaelovsky E, Rockah R, Amir I, Hermesh H, Laor N, et al. Association between obsessive-compulsive disorder and polymorphisms of genes encoding components of the serotonergic and dopaminergic pathways. Eur Neuropsychopharmacol. 2000 May; 10(3):205-209. [PubMed: 10793323]

51. Tot S, Erdal ME, Yazici K, Yazici AE, Metin O. T102C and -1438 G/A polymorphisms of the 5HT2A receptor gene in Turkish patients with obsessive-compulsive disorder. Eur Psychiatry. 2003 Aug; 18(5):249-254. [PubMed: 12927326]

52. Nicolini H, Cruz C, Camarena B, Orozco B, Kennedy JL, King N, et al. DRD2, DRD3 and 5HT2A receptor genes polymorphisms in obsessive-compulsive disorder. Mol Psychiatry. 1996 Dec; 1(6): 461-465. [PubMed: 9154247]

53. Hemmings SM, Kinnear CJ, Niehaus DJ, Moolman-Smook JC, Lochner C, Knowles JA, et al. Investigating the role of dopaminergic and serotonergic candidate genes in obsessive-compulsive disorder. Eur Neuropsychopharmacol. 2003 Mar; 13(2):93-98. [PubMed: 12650952]

54. Meira-Lima I, Shavitt RG, Miguita K, Ikenaga E, Miguel EC, Vallada H. Association analysis of the catechol-o-methyltransferase (COMT), serotonin transporter (5-HTT) and serotonin 2A receptor (5HT2A) gene polymorphisms with obsessive-compulsive disorder. Genes Brain Behav. 2004 Apr; 3(2):75-79. [PubMed: 15005715]

55. Hollander E, Prohovnik I, Stein DJ. Increased cerebral blood flow during m-CPP exacerbation of obsessive-compulsive disorder. J Neuropsychiatry Clin Neurosci. 1995 Fall;7(4):485-490. [PubMed: 8555752]

56. Chou-Green JM, Holscher TD, Dallman MF, Akana SF. Compulsive behavior in the 5-HT2C receptor knockout mouse. Physiol Behav. 2003 Apr; 78(4-5):641-649. [PubMed: 12782219]

57. Zohar J, Mueller EA, Insel TR, Zohar-Kadouch RC, Murphy DL. Serotonergic responsivity in obsessive-compulsive disorder. Comparison of patients and healthy controls. Arch Gen Psychiatry. 1987 Nov; 44(11):946-951. [PubMed: 3675134]

58. Charney DS, Goodman WK, Price LH, Woods SW, Rasmussen SA, Heninger GR. Serotonin function in obsessive-compulsive disorder. A comparison of the effects of tryptophan and $\mathrm{m}$ chlorophenylpiperazine in patients and healthy subjects. Arch Gen Psychiatry. 1988 Feb; 45(2): 177-185. [PubMed: 3337615]

59. Cavallini MC, Di Bella D, Pasquale L, Henin M, Bellodi L. 5HT2C CYS23/SER23 polymorphism is not associated with obsessive-compulsive disorder. Psychiatry Res. 1998 Feb 9; 77(2):97-104. [PubMed: 9541145]

60. el Mansari M, Bouchard C, Blier P. Alteration of serotonin release in the guinea pig orbitofrontal cortex by selective serotonin reuptake inhibitors. Relevance to treatment of obsessive-compulsive disorder. Neuropsychopharmacology. 1995 Oct; 13(2):117-127. [PubMed: 8597523]

61. Mundo E, Richter MA, Sam F, Macciardi F, Kennedy JL. Is the 5-HT(1Dbeta) receptor gene implicated in the pathogenesis of obsessive-compulsive disorder? Am J Psychiatry. $2000 \mathrm{Jul}$; 157(7):1160-1161. [PubMed: 10873927]

62. Mundo E, Richter MA, Zai G, Sam F, McBride J, Macciardi F, et al. 5HT1Dbeta Receptor gene implicated in the pathogenesis of Obsessive-Compulsive Disorder: further evidence from a familybased association study. Mol Psychiatry. 2002; 7(7):805-809. [PubMed: 12192628]

63. Di Bella D, Cavallini MC, Bellodi L. No association between obsessive-compulsive disorder and the 5-HT(1Dbeta) receptor gene. Am J Psychiatry. 2002 Oct; 159(10):1783-1785. [PubMed: 12359689]

64. Camarena B, Aguilar A, Loyzaga C, Nicolini H. A family-based association study of the 5HT-1Dbeta receptor gene in obsessive-compulsive disorder. Int J Neuropsychopharmacol. 2004 Mar; 7(1):49-53. [PubMed: 14731309] 
65. Mossner R, Walitza S, Geller F, Scherag A, Gutknecht L, Jacob C, et al. Transmission disequilibrium of polymorphic variants in the tryptophan hydroxylase-2 gene in children and adolescents with obsessive-compulsive disorder. Int J Neuropsychopharmacol. 2006 Aug; 9(4): 437-442. [PubMed: 16146581]

66. Billett EA, Richter MA, Sam F, Swinson RP, Dai XY, King N, et al. Investigation of dopamine system genes in obsessive-compulsive disorder. Psychiatr Genet. 1998 Autumn;8(3):163-169. [PubMed: 9800217]

67. Miguita K, Cordeiro Q, Siqueira-Roberto J, Shavitt RG, Castillo JC, Castillo AR, et al. Association analysis between a VNTR intron 8 polymorphism of the dopamine transporter gene (SLC6A3) and obsessive- compulsive disorder in a Brazilian sample. Arq Neuropsiquiatr. 2007 Dec; 65(4A):936941. [PubMed: 18094849]

68. Denys D, van der Wee N, Janssen J, De Geus F, Westenberg HG. Low level of dopaminergic D2 receptor binding in obsessive-compulsive disorder. Biol Psychiatry. 2004 May 15; 55(10):10411045. [PubMed: 15121489]

69. Catalano M, Sciuto G, Di Bella D, Novelli E, Nobile M, Bellodi L. Lack of association between obsessive-compulsive disorder and the dopamine D3 receptor gene: some preliminary considerations. Am J Med Genet. 1994 Sep 15; 54(3):253-255. [PubMed: 7810583]

70. Millet B, Chabane N, Delorme R, Leboyer M, Leroy S, Poirier MF, et al. Association between the dopamine receptor D4 (DRD4) gene and obsessive-compulsive disorder. Am J Med Genet B Neuropsychiatr Genet. 2003 Jan 1; 116B(1):55-59. [PubMed: 12497615]

71. Walitza S, Scherag A, Renner TJ, Hinney A, Remschmidt H, Herpertz-Dahlmann B, et al. Transmission disequilibrium studies in early onset of obsessive-compulsive disorder for polymorphisms in genes of the dopaminergic system. J Neural Transm. 2008 Jul; 115(7):10711078. [PubMed: 18446263]

72. Karayiorgou M, Sobin C, Blundell ML, Galke BL, Malinova L, Goldberg P, et al. Family-based association studies support a sexually dimorphic effect of COMT and MAOA on genetic susceptibility to obsessive-compulsive disorder. Biol Psychiatry. 1999 May 1; 45(9):1178-1189. [PubMed: 10331110]

73. Camarena B, Rinetti G, Cruz C, Gomez A, de La Fuente JR, Nicolini H. Additional evidence that genetic variation of MAO-A gene supports a gender subtype in obsessive-compulsive disorder. Am J Med Genet. 2001 Apr 8; 105(3):279-282. [PubMed: 11353450]

74. Grossman MH, Szumlanski C, Littrell JB, Weinstein R, Weinshilboum RM. Electrophoretic analysis of low and high activity forms of catechol-O-methyltransferase in human erythrocytes. Life Sci. 1992; 50(7):473-480. [PubMed: 1542252]

75. Azzam A, Mathews CA. Meta-analysis of the association between the catecholamine-O-methyltransferase gene and obsessive-compulsive disorder. Am J Med Genet B Neuropsychiatr Genet. 2003 Nov 15; 123B(1):64-69. [PubMed: 14582147]

76. Pooley EC, Fineberg N, Harrison PJ. The met(158) allele of catechol-O-methyltransferase (COMT) is associated with obsessive-compulsive disorder in men: case-control study and metaanalysis. Mol Psychiatry. 2007 Jun; 12(6):556-561. [PubMed: 17264842]

77. Pittenger C, Krystal JH, Coric V. Glutamate-modulating drugs as novel pharmacotherapeutic agents in the treatment of obsessive-compulsive disorder. NeuroRx. 2006 Jan; 3(1):69-81. [PubMed: 16490414]

78. Rosenberg DR, MacMaster FP, Keshavan MS, Fitzgerald KD, Stewart CM, Moore GJ. Decrease in caudate glutamatergic concentrations in pediatric obsessive-compulsive disorder patients taking paroxetine. J Am Acad Child Adolesc Psychiatry. 2000 Sep; 39(9):1096-1103. [PubMed: 10986805]

79. Coric V, Taskiran S, Pittenger C, Wasylink S, Mathalon DH, Valentine G, et al. Riluzole augmentation in treatment-resistant obsessive-compulsive disorder: an open-label trial. Biol Psychiatry. 2005 Sep 1; 58(5):424-428. [PubMed: 15993857]

80. Pittenger C, Kelmendi B, Wasylink S, Bloch MH, Coric V. Riluzole augmentation in treatmentrefractory obsessive-compulsive disorder: a series of 13 cases, with long-term follow-up. J Clin Psychopharmacol. 2008 Jun; 28(3):363-367. [PubMed: 18480706] 
81. Taylor LD, Krizman DB, Jankovic J, Hayani A, Steuber PC, Greenberg F, Fenwick RG, Caskey CT. 9p monosomy in a patient with Gilles de la Tourette syndrome. Neurology. 1991 Sep; 41(9): 1513-1515. [PubMed: 1679912]

82. Veenstra-VanderWeele J, Kim SJ, Gonen D, Hanna GL, Leventhal BL, Cook EH Jr. Genomic organization of the SLC1A1/EAAC1 gene and mutation screening in early-onset obsessivecompulsive disorder. Mol Psychiatry. 2001 Mar; 6(2):160-167. [PubMed: 11317217]

83. Dickel DE, Veenstra-VanderWeele J, Cox NJ, Wu X, Fischer DJ, Van Etten-Lee M, et al. Association testing of the positional and functional candidate gene SLC1A1/EAAC1 in early-onset obsessive-compulsive disorder. Arch Gen Psychiatry. 2006 Jul; 63(7):778-785. [PubMed: 16818867]

84. Arnold PD, Sicard T, Burroughs E, Richter MA, Kennedy JL. Glutamate transporter gene SLC1A1 associated with obsessive-compulsive disorder. Arch Gen Psychiatry. 2006 Jul; 63(7):769-776. [PubMed: 16818866]

85. Chabane N, Delorme R, Millet B, Mouren MC, Leboyer M, Pauls D. Early-onset obsessivecompulsive disorder: a subgroup with a specific clinical and familial pattern? J Child Psychol Psychiatry. 2005 Aug; 46(8):881-887. [PubMed: 16033636]

86. Stewart SE, Fagerness JA, Platko J, Smoller JW, Scharf JM, Illmann C, et al. Association of the SLC1A1 glutamate transporter gene and obsessive-compulsive disorder. Am J Med Genet B Neuropsychiatr Genet. 2007 Dec 5; 144B(8):1027-1033. [PubMed: 17894418]

87. Shugart YY, Wang Y, Samuels JF, Grados MA, Greenberg BD, Knowles JA, et al. A family-based association study of the glutamate transporter gene SLC1A1 in obsessive-compulsive disorder in 378 families. Am J Med Genet B Neuropsychiatr Genet. 2009 Jan 16.

88. Wendland JR, Moya PR, Timpano KR, Anavitarte AP, Kruse MR, Wheaton MG, et al. A haplotype containing quantitative trait loci for SLC1A1 gene expression and its association with obsessive-compulsive disorder. Arch Gen Psychiatry. 2009 Apr; 66(4):408-416. [PubMed: 19349310]

89. Welch JM, Lu J, Rodriguiz RM, Trotta NC, Peca J, Ding JD, et al. Cortico-striatal synaptic defects and OCD-like behaviours in Sapap3-mutant mice. Nature. 2007 Aug 23; 448(7156):894-900. [PubMed: 17713528]

90. Zuchner S, Wendland JR, Ashley-Koch AE, Collins AL, Tran-Viet KN, Quinn K, et al. Multiple rare SAPAP3 missense variants in trichotillomania and OCD. Mol Psychiatry. 2009 Jan; 14(1):69. [PubMed: 19096451]

91. Zai G, Bezchlibnyk YB, Richter MA, Arnold P, Burroughs E, Barr CL, et al. Myelin oligodendrocyte glycoprotein (MOG) gene is associated with obsessive-compulsive disorder. Am J Med Genet B Neuropsychiatr Genet. 2004 Aug 15; 129B(1):64-68. [PubMed: 15274043]

92. Arnold PD, Macmaster FP, Richter MA, Hanna GL, Sicard T, Burroughs E, et al. Glutamate receptor gene (GRIN2B) associated with reduced anterior cingulate glutamatergic concentration in pediatric obsessive-compulsive disorder. Psychiatry Res. 2009 May 15; 172(2):136-139. [PubMed: 19324536]

93. Rosenberg DR, Mirza Y, Russell A, Tang J, Smith JM, Banerjee SP, et al. Reduced anterior cingulate glutamatergic concentrations in childhood OCD and major depression versus healthy controls. J Am Acad Child Adolesc Psychiatry. 2004 Sep; 43(9):1146-1153. [PubMed: 15322418]

94. Delorme R, Krebs MO, Chabane N, Roy I, Millet B, Mouren-Simeoni MC, et al. Frequency and transmission of glutamate receptors GRIK2 and GRIK3 polymorphisms in patients with obsessive compulsive disorder. Neuroreport. 2004 Mar 22; 15(4):699-702. [PubMed: 15094479]

95. Maisonpierre PC, Le Beau MM, Espinosa R 3rd, Ip NY, Belluscio L, de la Monte SM, et al. Human and rat brain-derived neurotrophic factor and neurotrophin-3: gene structures, distributions, and chromosomal localizations. Genomics. 1991 Jul; 10(3):558-568. [PubMed: 1889806]

96. Egan MF, Kojima M, Callicott JH, Goldberg TE, Kolachana BS, Bertolino A, et al. The BDNF val66met polymorphism affects activity-dependent secretion of BDNF and human memory and hippocampal function. Cell. 2003 Jan 24; 112(2):257-269. [PubMed: 12553913] 
97. Chen ZY, Jing D, Bath KG, Ieraci A, Khan T, Siao CJ, et al. Genetic variant BDNF (Val66Met) polymorphism alters anxiety-related behavior. Science. 2006 Oct 6; 314(5796):140-143. [PubMed: 17023662]

98. Hall D, Dhilla A, Charalambous A, Gogos JA, Karayiorgou M. Sequence variants of the brainderived neurotrophic factor (BDNF) gene are strongly associated with obsessive-compulsive disorder. Am J Hum Genet. 2003 Aug; 73(2):370-376. [PubMed: 12836135]

99. Mossner R, Walitza S, Lesch KP, Geller F, Barth N, Remschmidt H, et al. Brain-derived neurotrophic factor V66M polymorphism in childhood-onset obsessive-compulsive disorder. Int $\mathbf{J}$ Neuropsychopharmacol. 2005 Mar; 8(1):133-136. [PubMed: 15638951]

100. Katerberg H, Lochner C, Cath DC, de Jonge P, Bochdanovits Z, Moolman-Smook JC, et al. The role of the brain-derived neurotrophic factor (BDNF) val66met variant in the phenotypic expression of obsessive-compulsive disorder (OCD). Am J Med Genet B Neuropsychiatr Genet. 2009 Feb 13.

101. Hemmings SM, Kinnear CJ, Van der Merwe L, Lochner C, Corfield VA, Moolman-Smook JC, et al. Investigating the role of the brain-derived neurotrophic factor (BDNF) val66met variant in obsessive-compulsive disorder (OCD). World J Biol Psychiatry. 2008; 9(2):126-134. [PubMed: 17853300]

102. Wendland JR, Kruse MR, Cromer KR, Murphy DL. A large case-control study of common functional SLC6A4 and BDNF variants in obsessive-compulsive disorder. Neuropsychopharmacology. 2007 Dec; 32(12):2543-2551. [PubMed: 17375136]

103. Dickel DE, Veenstra-VanderWeele J, Bivens NC, Wu X, Fischer DJ, Van Etten-Lee M, et al. Association studies of serotonin system candidate genes in early-onset obsessive-compulsive disorder. Biol Psychiatry. 2007 Feb 1; 61(3):322-329. [PubMed: 17241828]

104. Saxena S, Brody AL, Schwartz JM, Baxter LR. Neuroimaging and frontal-subcortical circuitry in obsessive-compulsive disorder. Br J Psychiatry Suppl. 1998; (35):26-37. [PubMed: 9829024]

105. Stewart SE, Platko J, Fagerness J, Birns J, Jenike E, Smoller JW, et al. A genetic family-based association study of OLIG2 in obsessive-compulsive disorder. Arch Gen Psychiatry. 2007 Feb; 64(2):209-214. [PubMed: 17283288]

106. Szeszko PR, Ardekani BA, Ashtari M, Malhotra AK, Robinson DG, Bilder RM, et al. White matter abnormalities in obsessive-compulsive disorder: a diffusion tensor imaging study. Arch Gen Psychiatry. 2005 Jul; 62(7):782-790. [PubMed: 15997020]

107. Jenike MA, Breiter HC, Baer L, Kennedy DN, Savage CR, Olivares MJ, et al. Cerebral structural abnormalities in obsessive-compulsive disorder. A quantitative morphometric magnetic resonance imaging study. Arch Gen Psychiatry. 1996 Jul; 53(7):625-632. [PubMed: 8660129]

108. Swedo SE, Leonard HL, Garvey M, Mittleman B, Allen AJ, Perlmutter S, et al. Pediatric autoimmune neuropsychiatric disorders associated with streptococcal infections: clinical description of the first 50 cases. Am J Psychiatry. 1998 Feb; 155(2):264-271. [PubMed: 9464208]

109. Beutler B, Cerami A. The biology of cachectin/TNF--a primary mediator of the host response. Annu Rev Immunol. 1989; 7:625-655. [PubMed: 2540776]

110. Mercadante MT, Busatto GF, Lombroso PJ, Prado L, Rosario-Campos MC, do Valle R, et al. The psychiatric symptoms of rheumatic fever. Am J Psychiatry. 2000 Dec; 157(12):2036-2038. [PubMed: 11097972]

111. Brinkman BM, Zuijdeest D, Kaijzel EL, Breedveld FC, Verweij CL. Relevance of the tumor necrosis factor alpha (TNF alpha)-308 promoter polymorphism in TNF alpha gene regulation. $\mathrm{J}$ Inflamm. 1995; 46(1):32-41. [PubMed: 8832970]

112. Zai G, Arnold PD, Burroughs E, Richter MA, Kennedy JL. Tumor necrosis factor-alpha gene is not associated with obsessive-compulsive disorder. Psychiatr Genet. 2006 Feb; 16(1):43-45. [PubMed: 16395130]

113. Hounie AG, Cappi C, Cordeiro Q, Sampaio AS, Moraes I, Rosario MC, et al. TNF-alpha polymorphisms are associated with obsessive-compulsive disorder. Neurosci Lett. 2008 Sep 12; 442(2):86-90. [PubMed: 18639610]

114. Hattersley AT, McCarthy MI. What makes a good genetic association study? Lancet. 2005 Oct 8; 366(9493):1315-1323. [PubMed: 16214603] 
115. Bogardus ST Jr, Concato J, Feinstein AR. Clinical epidemiological quality in molecular genetic research: the need for methodological standards. Jama. 1999 May 26; 281(20):1919-1926. [PubMed: 10349896]

116. Gordon D, Finch SJ, Nothnagel M, Ott J. Power and sample size calculations for case-control genetic association tests when errors are present: application to single nucleotide polymorphisms. Hum Hered. 2002; 54(1):22-33. [PubMed: 12446984]

117. Diagnostic and statistical manual of mental disorders: DSM-IV-TR. Washington D.C.: American Psychiatric Association; 2000.

118. Samuels J, Shugart YY, Grados MA, Willour VL, Bienvenu OJ, Greenberg BD, et al. Significant linkage to compulsive hoarding on chromosome 14 in families with obsessive-compulsive disorder: results from the OCD Collaborative Genetics Study. Am J Psychiatry. 2007 Mar; 164(3):493-499. [PubMed: 17329475]

119. Bacanu SA, Devlin B, Roeder K. The power of genomic control. Am J Hum Genet. 2000 Jun; 66(6):1933-1944. [PubMed: 10801388]

120. Bloch MH, Landeros-Weisenberger A, Kelmendi B, Coric V, Bracken MB, Leckman JF. A systematic review: antipsychotic augmentation with treatment refractory obsessive-compulsive disorder. Mol Psychiatry. 2006 Jul; 11(7):622-632. [PubMed: 16585942]

121. Bloch MH, Peterson BS, Scahill L, Otka J, Katsovich L, Zhang H, et al. Adulthood outcome of tic and obsessive-compulsive symptom severity in children with Tourette syndrome. Arch Pediatr Adolesc Med. 2006 Jan; 160(1):65-69. [PubMed: 16389213]

122. March JS, Franklin ME, Leonard H, Garcia A, Moore P, Freeman J, et al. Tics moderate treatment outcome with sertraline but not cognitive-behavior therapy in pediatric obsessivecompulsive disorder. Biol Psychiatry. 2007 Feb 1; 61(3):344-347. [PubMed: 17241830] 


\section{TABLE}

Studies implicating the Slc1a1 gene in OCD.

\begin{tabular}{|c|c|c|c|c|}
\hline Authors & Design & Subjects & Principal findings & Reference \\
\hline $\begin{array}{l}\text { Taylor et al, } \\
1991\end{array}$ & Case report & $\begin{array}{l}1 \text { subject with Tourette } \\
\text { syndrome, OCD, and } \\
\text { ADHD }\end{array}$ & Deletion of terminal portion of $9 p$ & 81 \\
\hline $\begin{array}{l}\text { Hanna et al, } \\
2002\end{array}$ & Genome-wide linkage analysis & $\begin{array}{l}56 \text { individuals from } 7 \\
\text { families, with pediatric- } \\
\text { onset probands }\end{array}$ & $\begin{array}{l}\text { Maximum linkage score }(\mathrm{LOD}= \\
2.25) \text { on at } 9 \mathrm{p} 24\end{array}$ & 26 \\
\hline $\begin{array}{l}\text { Veenstra- } \\
\text { Vander Weele } \\
\text { et al, } 2001\end{array}$ & $\begin{array}{l}\text { Analysis of the genomic structure of } \\
\text { Slc1a1 and sequencing of coding } \\
\text { sequence }\end{array}$ & 7 probands from ref. 26 & $\begin{array}{l}\text { Several SNPs identified; no clear } \\
\text { functional SNP }\end{array}$ & 82 \\
\hline $\begin{array}{l}\text { Willour et al, } \\
2004\end{array}$ & Sib-pair analysis & $\begin{array}{l}50 \text { sib-pairs, } 42 \text { with } \\
\text { narrow-phenotype OCD }\end{array}$ & Replication of linkage at 9p24 & 31 \\
\hline $\begin{array}{l}\text { Dickel et al, } \\
2006\end{array}$ & $\begin{array}{l}\text { Family-based candidate gene } \\
\text { association study }\end{array}$ & $\begin{array}{l}71 \text { trios with early-onset } \\
\text { probands; one } \\
\text { multigenerational OCD } \\
\text { pedigree }\end{array}$ & $\begin{array}{l}\text { Linkage to } 2 \text { SNPs within Slc1a1; } \\
\text { significance at one of these was } \\
\text { limited to male probands }\end{array}$ & 83 \\
\hline $\begin{array}{l}\text { Arnold et al, } \\
2006\end{array}$ & $\begin{array}{l}\text { Family-based candidate gene } \\
\text { association study }\end{array}$ & $\begin{array}{l}157 \text { probands and their } \\
\text { first-degree relatives }\end{array}$ & $\begin{array}{l}\text { Significant linkage to } 2 \text { SNPs and } \\
\text { one haplotype within Slc1a1; } \\
\text { haplotype linkage was significant } \\
\text { only with male probands. }\end{array}$ & 84 \\
\hline $\begin{array}{l}\text { Stewart et al, } \\
2007\end{array}$ & $\begin{array}{l}\text { Family-based candidate gene } \\
\text { association study }\end{array}$ & $\begin{array}{l}66 \text { probands and their first- } \\
\text { degree relatives }\end{array}$ & $\begin{array}{l}\text { Significant association with a three- } \\
\text { marker haplotype in both males and } \\
\text { females, and with two individual } \\
\text { markers }\end{array}$ & 86 \\
\hline $\begin{array}{l}\text { Shugart et al, } \\
2009\end{array}$ & $\begin{array}{l}\text { Family-based candidate gene } \\
\text { association study }\end{array}$ & 378 families & $\begin{array}{l}\text { Significant association with a } \\
\text { marker outside the Slc1a1 gene }\end{array}$ & 87 \\
\hline $\begin{array}{l}\text { Wendland et al, } \\
2009\end{array}$ & $\begin{array}{l}\text { Case-control association study; in } \\
\text { vitro expression study }\end{array}$ & $\begin{array}{l}325 \text { subjects with OCD; } \\
662 \text { matched controls }\end{array}$ & $\begin{array}{l}\text { Significant association with } 2 \\
\text { haplotypes within Slc1a1, and one } \\
\text { novel 5' haplotype associated with } \\
\text { hoarding; stronger association in } \\
\text { males }\end{array}$ & 88 \\
\hline
\end{tabular}

